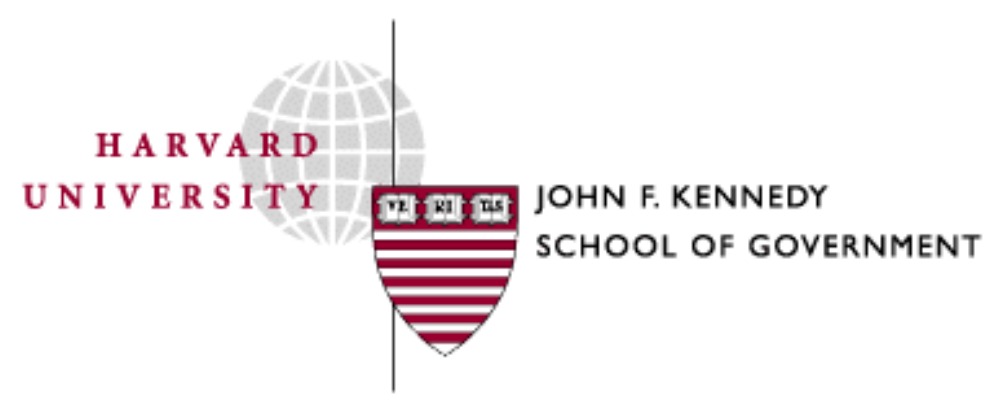

Faculty Research Working Papers Series

\title{
Corporate Structure and the Financial Support Of U.S. Symphony Orchestras
}

\author{
F. M. Scherer \\ John F. Kennedy School of Government - Harvard University
}

January 2007

RWP07-002

The views expressed in the KSG Faculty Research Working Paper Series are those of the author(s) and do not necessarily reflect those of the John F. Kennedy School of Government or of Harvard University. Faculty Research Working Papers have not undergone formal review and approval. Such papers are included in this series to elicit feedback and to encourage debate on important public policy challenges. Copyright belongs to the author(s). Papers may be downloaded for personal use only. 


\title{
Abstract \\ CORPORATE STRUCTURE AND THE FINANCIAL SUPPORT \\ OF U.S. SYMPHONY ORCHESTRAS
}

\author{
F. M. Scherer \\ Harvard University \\ August 2006
}

The United States experienced merger waves of unprecedented proportions during the 1980s and 1990s. After mapping the resulting relocation of corporate headquarters among metropolitan areas, this article investigates how relocations affected the financial status of leading American symphony orchestras, which depend for support upon philanthropic contributions from corporations and gifts from listeners, including corporate staff. The size of orchestras' budgets is explained most strongly in a panel analysis by local income percapita and the magnitude of their endowments. Endowments in turn depend upon income per-capita and the amount of assets controlled by corporations headquartered in the area served by orchestras.

JEL Codes: Z11, L29 


\title{
CORPORATE STRUCTURE AND THE FINANCIAL SUPPORT OF U.S. SYMPHONY ORCHESTRAS
}

\author{
F. M. Scherer \\ August 2006
}

Under the almost uniquely American approach to financing cultural activities, elite institutions such as symphony orchestras derive appreciable financial support from corporations, both directly in the form of philanthropic grants and indirectly through gifts and subscriptions from well-paid employees. Such support is important to symphony orchestras -in view of recent orchestra closures and strikes, an endangered species. In part because Baumol's cost disease requires musicians' wages to rise more rapidly than productivity growth, ${ }^{1}$ symphony orchestras in the United States typically fall far short of balancing their budgets through direct ticket sales and must fill the gap through contributions. During the 2002-03 season, for example, admissions receipts for 42 leading U.S. orchestras defrayed on average only 43 percent of their operating budgets. For the ten orchestras with the largest 2002-03 budgets, state, local, and federal government grants averaged 4.1 percent of budgets. ${ }^{2}$ For the same orchestras, private foundation grants defrayed 3.7 percent of budgets. The balance had to come from annual giving and endowment funds.

Broad-ranging studies of corporate philanthropy reveal that the lion's share of direct corporate contributions - - as much as 60 to 80 percent - - is targeted toward organizations located in the same metropolitan area as the corporate headquarters. ${ }^{3}$ Beginning at least with the convening of a Columbia University Law School conference in 1982 (Bock et al., 1984), if not earlier, there has been concern about how corporate mergers,

1 . See Baumol and Bowen (1965) and Dempster (2000). Record sales could broaden audiences and blunt the law's working, but the classical music record market has been saturated for many years.

2 . Washington's National Symphony Orchestra had the highest fraction, 14.7 percent, obtained mainly from the federal government.

3 . See e.g. McElroy and Siegfried (1984, pp. 124, 126. 129, and 147); and Marquis and Davis (2004, p. 15). 
consolidations, and headquarters relocations affect the support of philanthropic efforts generally and elite cultural institutions such as symphony orchestras in particular.

This paper undertakes two main tasks. First, it assesses how recent merger waves have affected the geographic pattern of corporate headquarters locations. And second, using data on the changing locations of those headquarters and the assets they control, it analyzes econometrically the impact of headquarters location on the size of symphony orchestra endowments and operating budgets.

\section{The Merger Record}

Given a focus on symphony orchestras among the many charitable causes that benefit from corporate philanthropy, the corporate headquarters data were organized to mesh with metropolitan areas served by 44 U.S. symphony orchestras, on which detailed financial data spanning 1980 to 2003 were available from annual surveys by the American Federation of Musicians. ${ }^{4}$ Excluded from the analysis were operas and ballets, with quite different operating cost structures, and one orchestra (Chicago's Grant Park Symphony) that held only free performances. For each orchestra, a corresponding service area was defined, typically entailing at most three-quarters of an hour's off-peak commute to the performance venue. These were sometimes broader than standard metropolitan statistical areas. Two broad exceptions were made, for the North Carolina Symphony Orchestra and the New Jersey Symphony, which regularly offer concerts at multiple locations in their home states. For these, nearly statewide areas were defined. ${ }^{5}$ once these areas plus a

$4 \quad$. The annual report, typically titled Wage Scales and Conditions in the Symphony Orchestra, is issued by annual season (spanning two calendar years). The author is indebted to AFM president Jan Gippo for facilitating access to the data at the federation's New York City headquarters, to Eric Beers for organizing the needed documents, and to Jerry Wigner for informing the author of their existence.

5 . For North Carolina, the definition was strictly statewide. Excluded from the New Jersey Symphony Orchestra's areas were the Philadelphia suburbs around Camden and the West Hudson River bank suburbs of New York City (excluding Newark). The Virginia Symphony Orchestra had similar statewide mobility, but missing budget data required its deletion from the final sample. New York City's area was assumed to encompass Westchester County and the 
separate area for suburban southern connecticut had been defined, a "rest of the lower 48 states" area not served by symphony orchestras remained. For 1982, it encompassed 8.56 percent of relevant corporation assets, as assigned to headquarters locations, and 47.84 percent of 1980 U.S. population. For 2002, its corporate asset share was 12.40 percent and its 2000 population share 47.20 percent. Thus, not surprisingly, symphony orchestras and corporate headquarters are both located preponderantly in densely populated urban areas.

The variable used to measure corporations' philanthropic potential and their employees' donation capability is total assets. Prior analyses reveal that corporate philanthropic contributions are most closely related to profits and (especially for cultural grants) advertising outlays. ${ }^{6}$ However, profits vary widely from year to year, and for a large sample with considerable entry and exit, assets were considered a more stable measure of corporate plus employee financial capability. obtaining matched advertising data would have been prohibitively difficult.

Data for the analysis of corporate headquarters locations and the restructuring activity that changed them were drawn from Fortune magazine's annual "500" lists. Given the increasing share of gross national product originating in the services sector and the declining share of manufacturing (the main thrust of Fortune's broader industrials category), covering both was important. However, because managing paper asset accumulations is vastly simpler for financial corporations than for other enterprises, rendering asset values non-comparable, banks, diversified financial corporations, and insurance companies were excluded from all tabulations. Fortune first began publishing data for the 500 largest service corporations in 1982, so 1982 was taken as the starting year for analyzing asset - orchestra budget relationships. The terminal year, chosen to match the Fortune data with lagged orchestra budget data availability, was 2002. To allow additional time series variation, data were added for an intermediate year, $1993 .{ }^{7}$

western third of Long Island. San Francisco's area was drawn (assuming off-peak traffic and uniquely Californian driving habits) to extend through San Jose. Most of the other definitions were straightforward.

6 . See e.g. Useem and Kutner (1986), Navarro (1988), and Leclair and Gordon (2000).

7 . After 1994, Fortune ceased publishing separate lists for industrials and service companies, 
Turnover among the leading corporations during the two decades analyzed was in fact high and by post-1920s standards unprec-edentedly high. ${ }^{8}$ Due to extensive changes over time in the qualifications for inclusion on Fortune's service list, a close comparison can be made only for industrial corporations. Between 1982 and 1993, 115 companies disappeared from the Fortune 500 industrials list by merger; 17 more exited through "going private" transactions, which often had merger-like characteristics. Between 1993 and 2002, 110 of the top 500 companies in 1993 disappeared through merger, and eight more exited by going private. ${ }^{9}$ For companies that remained on lists of top industrials, changes of headquarters location were less frequent. There were 27 such changes out of 293 survivors, or 9.2 percent, between 1982 and 1993, and 14 out of 258 survivors, or 5.4 percent, between 1993 and 2002 .

The large number of mergers along with some unrelated relocation decisions led to substantial changes in corporate headquarters locations and in the amount of assets controlled by corporations headquartered at diverse locations. For each listed industrial and service corporation in each of the years 1982, 1993, and 2002, total asset figures were extracted from the Fortune lists and assigned to metropolitan areas, defined in terms of symphony orchestras' presumed reach, according to their corporate headquarters locations. The number of recorded headquarters locations ranged from 104 for New York City in 1982 (reduced to 52 in 2002) and 70 for Chicago in 1982 (reduced to 46 in 2002) down to one each in 1982 for Syracuse and Buffalo (each reduced to zero in 2002). ${ }^{10}$ The largest absolute headquarters count increases were experienced by San Francisco (from 23 to 45), the District of Columbia (from 7 to 20), and

merging them into a single "top 1000" list. Using Fortune's more detailed breakdowns and other sources, the 2002 data were separated into the two previous categories.

8 . For a more detailed analysis of merger patterns, see Scherer (2006).

9 . For 1982-93, 69 additional companies exited from the top 500 list, in most cases to continue existence in a smaller size category. For 1993-2002, the number of additional disappearances for non-merger reasons (including reclassification to services and foreign ownership) was 126.

10 . The total number of corporations included in the locational matchings was 749 for 1982 and 747 for 2002. 
Houston (from 26 to 38). Turning to the dollar value of assigned assets, we find that New York City had the largest total asset shares in both years: 27.81 percent in 1982 and 14.09 percent in 2002. Taking the ratio of 2002 to 1982 asset shares, the six largest proportional gainers were:

\begin{tabular}{lccc} 
City & 1982 Percent Share & & 2002 Share / 1982 Share \\
\cline { 2 - 2 } Denver & 0.28 & & \\
District of Columbia & 0.38 & & 5.04 \\
San Antonio & 0.11 & & 3.99 \\
Columbus, Ohio & 0.81 & & 3.59 \\
Seattle & 0.97 & & 2.53 \\
Atlanta & 1.53 & & 2.39 \\
& &
\end{tabular}

The most severely impacted asset share losers, all but Pittsburgh with small initial shares, were:

City 1982 Percent Share 2002 Share / 1982 Share

Buffalo 0.01 0

Syracuse

0.22

0

New Or leans

0.87

Pittsburgh

3.71

$\odot .06$

Portland, Oregon

0.45

0.20

Louisville

0.48

0.32

0.38

None of the six largest proportional gainers or losers were metropolitan areas in which the long-established "Big Five" of American symphony orchestras resided -- i.e., Chicago, Boston, Philadelphia, Cleveland, and New York. On average, the asset shares of those five declined by 18 percent. Cleveland fared worst with a 61.5 percent loss of position relative to its 1982 share; Philadelphia fared best with a 50.5 percent gain.

From a broader perspective, the changes in corporate headquarters locations led to greater equality of the distribution of asset control throughout the United States. The share of all sample corporation assets headquartered in the eight leading asset-attracting metropolitan areas was 63.4 
percent in 1982 and 55.8 percent in 2002. ${ }^{11}$ Previously neglected areas gained at their expense.

\section{Headquarters Locations and Orchestra Budgets}

We advance now to our next question: how the changing pattern of U.S. corporate headquarters location affected, if indeed it did, the level of financial support enjoyed by major unionized symphony orchestras. The principal variable used to measure financial support is an orchestra's total annual budget for the 2002-03 season. These ranged from an average of $\$ 50.1$ million for the above-named Big Five to $\$ 6.2$ million for the five lowest-budget orchestras on which data were available. Budget levels strongly influence orchestra members' minimum annual salaries, which in turn affect an orchestra's competitiveness in the world-wide market for talent. Minimum salary levels were correlated with 2002-03 budgets at +0.943 in the logarithms and +0.898 untransformed. A regression in the logarithms (to base 10) of salaries on budgets was as follows:

$$
\text { Log SALARY }=\frac{3.98}{(85.03)}+\underset{(17.06)}{0.625} \log \text { BUDGET; } \mathrm{R}^{2}=0.890 ; \mathrm{N}=38 ;
$$

with t-ratios in subscripted parentheses. The below-unity coefficient on the budget variable suggests that less affluent orchestras economize by employing fewer musicians and holding shorter seasons as well as paying lower minimum salaries.

Hypothesized Links

Corporate headquarters locations in metropolitan areas and the assets their executives command are believed to affect the fortunes of local symphony orchestras in various ways. For one, corporations make direct gifts to cultural activities, including orchestras. Prior studies have identified a variety of motives for corporate grants to the arts, ranging from enhancing good will through reducing personnel costs to the gratification of

11 . Included among the eight leaders are the relatively distant Connecticut suburbs of New York City, whose assets are not included in later analyses of the New York Philharmonic Orchestra's asset base. With all 45 coded areas included in the analysis, the coefficient of variation for asset shares declined from 1.994 in 1982 to 1.485 in 2002. 
managerial egos. ${ }^{12}$ For contributions from headquarters staff members, appreciation for the arts must be added as an element of individual utility functions.

Previous research has shown that a disproportionate share of corporations' philanthropy is directed toward causes in the headquarters area, and corporate cultural gifts are biased toward elite activities. ${ }^{13}$ Although the actual location of assets is usually dispersed widely, ultimate command over those assets is concentrated at the corporate headquarters, and for that reason all assets are assigned here to the headquarters location. Headquarters staffs include a disproportionate number of well-educated, well-paid executives and staff members who comprise a significant component of symphony orchestras' potential audience. Some subset make voluntary contributions to orchestras' annual fund-raising campaigns above and beyond subscription prices. A still smaller fraction contribute to orchestra permanent endowment funds. A reciprocal relationship strengthens corporations' willingness to make direct philanthropic contributions to orchestra fund-raising. Having high-quality cultural organizations in one's headquarters location helps in the recruitment of able executives and staff. And of course, corporations' direct philanthropic gifts and also gifts by their staff are tax-deductible under U.S. law, which means that the federal government provides substantial "tax expenditure" support for such cultural activities -- support that dwarfs the magnitude of direct Federal grants to cultural organizations, e.g., through the National Endowment for the Arts. ${ }^{14}$

Given the localized bias of corporate cultural philanthropy, mergers and other corporate control transactions that displace headquarters from a metropolitan area can be expected to lead to lower direct contributions and, by encouraging the out-migration of well-paid officials, reduce

12 . See Useem and Kutner (1986, p. 103); Navarro (1988); O'Hagan and Harvey (2000); Leclair and Gordon (2000); and Caves (2000, pp. 251-252).

13 . See again McElroy and Siegfried (1984) and Marquis and Davis (2004), and, for a review of earlier studies and a test suggesting that corporate contributions to the arts are for image enhancement, Leclair and Gordon (2000).

14 . See Schuster (2004) and (for an historical perspective) Katz (2004). 
audience and annual giving potential. However, another more subtle effect could work in the opposite direction. For the subset of corporations with appreciable owner-manager stockholding positions, an acquisition means that the ownermanagers, who commonly consider the headquarters location their home (or at least one of their homes ${ }^{15}$ ), realize sudden capital gains and/or cash windfalls, or they receive the stocks of companies with which they no longer have a direct empathetic connection and which they are likely to sell in order to achieve portfolio diversification. In the wake of such transactions, wealthy former stockholders are in a better position to make, and may choose to make, substantial philanthropic gifts, among other things, to local orchestra endowment funds. The motive for such gifts may be intensified by the tax shield philanthropic gifts provide against what could otherwise be capital gains tax obligations. Thus, the acquisition of a local corporation could in principle enrich the home-town orchestra's endowment, at least in the short run and possibly for a substantial period thereafter.

\section{A Pilot Study}

To enhance insight into the phenomena explored, an analysis was conducted of contributors to the Philadelphia Orchestra, as listed in its March 2005 Playbill. Among the industrial and commercial organizations enumerated as making annual contributions of $\$ 10,000$ or more, 17 were unambiguously headquartered in the Philadelphia area, or 21 if law firms are included, and eight might be viewed as outsiders. Many of the business organization donors were too small to be included on Fortune 1000 lists. Several outsider donors merit more detailed comment. Two pharmaceutical firms, Merck and Wyeth, had headquarters offices in New Jersey, too far from Philadelphia to be considered within normal concert-attending distance. However, both operated their principal R\&D laboratories in the Philadelphia area, and for pharmaceutical firms, attracting first-rate R\&D personnel is crucial to company fortunes. ${ }^{16}$ Three were non-resident banks: Bank of America,

15 . On leading orchestras' efforts to win endowment gifts from local residents wintering in Florida, see Dobrin (2005).

16 . In 2005, Public Radio broadcasts of the Indianapolis Symphony Orchestra were sponsored financially by Dr. August Watanabe, executive vice president emeritus for science and 
PNC, and Wachovia. Marquis and Childs (2004, p. 12) attribute Philadelphia's financial problems during the 1980s in part to the decline of locally headquartered banks from 12 to one and note that the hold-out was acquired by a North Carolina firm (ultimately, Wachovia) in 1997. But all three of the Philadelphia Orchestra donor banks retained regional headquarters offices in Philadelphia, and success in banking may depend more upon local relationships and good will than it does e.g. in manufacturing enterprises. ${ }^{17}$

Among the non-governmental foundations making annual contributions of $\$ 10,000$ or more, 20 were of local origin and six were outsiders. Some of the latter were known for reaching out widely throughout the United States to support cultural activities. Among the foundations contributing $\$ 1$ million or more to the orchestra's endowment campaign, all five had Philadelphia roots.

An attempt to determine the corporate or other affiliations of 102 individuals or families listed as contributors of $\$ 10,000$ or more to the 2004-05 annual fund and the nine contributing $\$ 1$ million or more to the endowment fund yielded meager fruit. ${ }^{18}$ At most 18 annual contributors and one endowment donor could be identified through listings in Who's who in America or the author's direct knowledge. Evidently, most individual contributions come from quiet money or old money or some combination of the two. Of those who could be identified, virtually all had connections to Philadelphia area businesses and/or resided in the Philadelphia area.

Statistical Analysis

Reassured that localization is indeed important, we proceed

technology of Eli Lilly \& Co.

17 . See e.g. the quotation from Kennedy Thompson, chairman of the Wachovia Corporation, with a regional headquarters in Philadelphia whose executives had substantial discretion to make local grants: "In Philadelphia, the banking business isn't as consolidated as in some other parts of the country, so we have to operate like this is our headquarters." "Making Themselves At Home," Philadelphia Inquirer, May 8, 2005, p. E1.

18 . Excluded from the analysis were two past or incumbent music directors plus one visiting maestro, Simon Rattle. 
to the statistical analysis. Sufficient information was available from American Federation of Musicians surveys to include 35 urban area orchestras in the sample (merging two Minneapolis - St. Paul orchestras into a combined entity).

Even after the exclusion of other orchestras for which insufficient data were available - - usually because of late starts or midterm failures - - a few missing observations remained on certain variables. The linkage of orchestra financial data with Fortune 1000 data permitted a panel analysis with three asset time slices over a 20-year interval, centered on 1982, 1993, and 2002 .

From the Fortune data set, the variables measured were ASSETS, the total value of assets of sampled industrial and service corporations with headquarters in the vicinity of an orchestra's home; and COUNT, the number of sampled corporations with headquarters in the orchestra's vicinity. From the considerable number of smaller donors who were contributors to the Philadelphia Orchestra, it is recognized that the numerical scope and diversity of the corporate establishment in an area may be as important to philanthropic support as the absolute amount of assets controlled at local headquarters. For each localized area, the POPULATION of the most closely corresponding standard metropolitan statistical areas was measured. These were drawn for the years 1980, 1990, and 2000 and linked with a forward lag (e.g., allowing adjustment to a new residence) to the most closely adjacent Fortune data measurement years.

An additional explanatory variable, INCOME, measures personal income per capita in the closest possible metropolitan area approximations to the symphony orchestra territories. ${ }^{19}$ Availability constraints necessitated modest mismatches with the asset and orchestra data; the INCOME data were for calendar years 1983, 1994, and 2003. The variable has at least two rationales. Higher personal incomes per capita might facilitate more generous support of orchestras, and higher local incomes increase the opportunity costs of resident musicians, requiring higher salaries and hence, all else equal, larger budgets. In

19 . It was derived from U.S. Department of Commerce, 1986 and 1997-98 editions, and Gaquin and de Brandt (2006). The measure deployed is an average rather than the more commonly used median. Averages place more weight on the highest income-earners, who are more likely to support elite institutions. 
introducing INCOME, we must be wary of multicollinearity. The correlation between it and ASSETS (in the logarithms) is +0.50 , and between it and POP $+\odot .66$.

From the American Federation of Musicians data set, two main dependent variables were extracted: BUDGET, i.e., the orchestra's operating budget in a relevant panel season; and ENDOW, or the size of the orchestra's endowment in the most closely matched panel year. The data covered seasons beginning in 1982, 1995, and 2003. The ENDOW values ranged from $\$ 247$ million (Boston in 2002) down in many cases to less than $\$ 1$ million. For ENDOW there were four missing observations -possibly but not necessarily because endowments had declined to zero.

All monetary variables were deflated to 1982 price levels using the Consumer Price Index. Most of the variables were skew cross-sectionally. To avoid the extreme value problems such skew distributions cause, logarithms (to base 10) were taken. ${ }^{20}$ Deviations of the conventional skewness coefficient for the logarithmically transformed variables from the zero value implying a normal distribution were for the most part small and statistically insignificant. Logarithmic transformations also permit estimates of the elasticity of measured relationships, with coefficient values of unity indicating proportionality, with neither diminishing nor increasing returns.

Table 1 reports the principal ordinary least squares regression estimates with BUDGET as the dependent variable. The first cluster of four regressions is for all observations pooled with various explanatory variable combinations. T-ratios are in all cases reported in subscripted parentheses. Equation (1.1) in that cluster reveals that the larger the population of the area an orchestra serves, the more constant-dollar corporate assets headquartered in that area, and the higher local income per capita, the larger is the orchestra's (constant-dollar) budget, with significantly diminishing marginal returns in all but the income relationship. ${ }^{21}$ Equation (1.3) substitutes for

20 . To take logarithms, two zero asset values were "plugged" at $\$ 1$ billion -- less than for any city with positive values. Two corresponding count values were plugged at unity.

21 . A variable measuring differences in the cost of living, defined only for 1996, had a positive sign but was consistently below conventional statistical significance levels. 
the assets variable the variable counting the number of corporate headquarters. The count variable explains orchestra budgets at least as well as the asset variable, suggesting preliminarily that diversity of urban business bases is as important as the sheer size of corporations headquartered in a city. When the size of orchestras' endowments is added in regressions (1.2) and (1.4), the population effects hold up, but the ASSET and COUNT variables fade to insignificance, overwhelmed by the strong ENDOW effect. $R^{2}$ values also rise sharply with ENDOW. This suggests a more complex relationship to be explored subsequently.

The second and third clusters of regressions attempt to discriminate between cross-sectional effects (the Across cases) and effects attributable to the change of variables over time (the 
Table 1: REGRESSIONS WITH LOG BUDGET AS DEPENDENT VARIABLE*

\begin{tabular}{|c|c|c|c|c|}
\hline & $(1.1)$ & $(1.2)$ & $(1.3)$ & $(1.4)$ \\
\hline \multicolumn{5}{|c|}{ Pooled } \\
\hline POPULATION & $\begin{array}{c}.306 \\
(2.76)\end{array}$ & $\begin{array}{c}.323 \\
(4.07)\end{array}$ & $\begin{array}{c}.182 \\
(1.53)\end{array}$ & $\begin{array}{r}.305 \\
(3.47)\end{array}$ \\
\hline ASSETS & $\begin{array}{l}163 \\
(3.09)\end{array}$ & $\begin{array}{l}.015 \\
(0.36)\end{array}$ & & \\
\hline ENDOWMENT & & $\begin{array}{l}.279 \\
(9.84)\end{array}$ & & $\begin{array}{r}.276 \\
(9.28)\end{array}$ \\
\hline COUNT & & & $\begin{array}{c}.307 \\
(4.03)\end{array}$ & $\begin{array}{r}.036 \\
(0.57)\end{array}$ \\
\hline INCOME & $\begin{array}{c}.981 \\
(3.47)\end{array}$ & $\begin{array}{c}.217 \\
(1.99)\end{array}$ & $\begin{array}{c}1.14 \\
(4.27)\end{array}$ & $\begin{array}{r}.457 \\
(2.12)\end{array}$ \\
\hline INTERCEPT & $\begin{array}{l}-4.97 \\
(4.51)\end{array}$ & $\begin{array}{l}-2.34 \\
(2.71)\end{array}$ & $\begin{array}{l}-4.78 \\
(4.50)\end{array}$ & $\begin{array}{l}-2.35 \\
2.75)\end{array}$ \\
\hline $\mathrm{N}$ & 103 & 100 & 103 & 100 \\
\hline $\mathrm{R}^{2}$ & .583 & .796 & .619 & .797 \\
\hline & & Across & & \\
\hline POPULATION & $\begin{array}{c}.160 \\
(0.80)\end{array}$ & $\begin{array}{c}.316 \\
(2.43)\end{array}$ & $\begin{array}{c}.035 \\
(0.18)\end{array}$ & $\begin{array}{r}.285 \\
(2.02)\end{array}$ \\
\hline ASSETS & $\begin{array}{c}.234 \\
(2.41)\end{array}$ & $\begin{array}{c}.003 \\
(0.04)\end{array}$ & & \\
\hline ENDOWMENT & & $\begin{array}{c}.303 \\
(6.79)\end{array}$ & & $\begin{array}{r}.295 \\
(6.24)\end{array}$ \\
\hline COUNT & & & $\begin{array}{l}.457 \\
(3.13)\end{array}$ & $\begin{array}{r}.040 \\
(0.34)\end{array}$ \\
\hline INCOME & $\begin{array}{c}1.18 \\
(1.31)\end{array}$ & $\begin{array}{c}.587 \\
(1.01)\end{array}$ & $\begin{array}{c}.613 \\
(.686)\end{array}$ & $\begin{array}{r}.532 \\
(0.89)\end{array}$ \\
\hline
\end{tabular}


Table 1 (Continued)

\begin{tabular}{|c|c|c|c|c|}
\hline INTERCEPT & $\begin{array}{l}-5.60 \\
(1.61)\end{array}$ & $\begin{array}{l}-2.93 \\
(1.30)\end{array}$ & $\begin{array}{l}-2.24 \\
(0.62)\end{array}$ & $\begin{array}{r}-2.62 \\
(1.07)\end{array}$ \\
\hline $\mathrm{N}$ & 35 & 35 & 35 & 35 \\
\hline $\mathrm{R}^{2}$ & .613 & .842 & .651 & .848 \\
\hline \multicolumn{5}{|c|}{ Within } \\
\hline POPULATION & $\begin{array}{c}.362 \\
(1.70)\end{array}$ & $\begin{array}{l}.354 \\
(1.42)\end{array}$ & $\begin{array}{c}.370 \\
(1.77)\end{array}$ & $\begin{array}{r}.382 \\
1.85)\end{array}$ \\
\hline ASSETS & $\begin{array}{l}-0.05 \\
(1.26)\end{array}$ & $\begin{array}{r}-.320 \\
(0.76)\end{array}$ & & \\
\hline ENDOWMENT & & $\begin{array}{r}.052 \\
(1.42)\end{array}$ & & $\begin{array}{r}.057 \\
(1.55)\end{array}$ \\
\hline COUNT & & & $\begin{array}{l}-.100 \\
(1.63)\end{array}$ & $\begin{array}{r}-.090 \\
(1.46)\end{array}$ \\
\hline INCOME & $\begin{array}{c}1.35 \\
(8.54)\end{array}$ & $\begin{array}{l}1.21 \\
(6.67)\end{array}$ & $\begin{array}{c}1.27 \\
(8.30)\end{array}$ & $\begin{array}{r}1.13 \\
(6.29)\end{array}$ \\
\hline INTERCEPT & $\begin{array}{l}-.003 \\
(0.39)\end{array}$ & $\begin{array}{l}-.0 \odot 4 \\
(0.50)\end{array}$ & $\begin{array}{l}-.003 \\
(0.38)\end{array}$ & $\begin{array}{r}-.004 \\
(\odot .51)\end{array}$ \\
\hline $\mathrm{N}$ & 103 & 100 & 103 & 100 \\
\hline $\mathrm{R}^{2}$ & .649 & .659 & .642 & .678 \\
\hline
\end{tabular}


Within cases). ${ }^{22}$ With the principal exception of the INCOME variable, which is consistently insignificant, the Across results parallel those obtained with pooled data. When population counts and corporate presence measures alone are analyzed, both have significant explanatory power, with the count variable performing somewhat more strongly than the assets variable. Again, ENDOW overwhelms those two when they must compete for explanatory power. The Within cluster suggests a quite different pattern. The INCOME variable overpowers POPULATION, ASSETS, and COUNT, with most of which it is collinear. ${ }^{23}$ Compared to regressions without INCOME, in which ENDOWMENT and POPULATION have significant explanatory power, the value of $R^{2}$ also rises appreciably - - e.g., from 0.519 to .0.659 in the analogue of regression (1.2) and from 0.543 to 0.678 in the analogue of regression (1.4). Changes in the assets controlled by corporations headquartered in an area and in the COUNT variable exhibit paradoxical negative but statistically insignificant relationships. These results might support the hypothesis that as mergers remove corporate headquarters from a locality, reducing headquarters counts and assets, contributions to orchestras rise as local stockholders enriched by tendering to the acquiring corporation the shares they hold devote some of their new, more diversified wealth to cultural philanthropy. Changes in income per capita are clearly the main determinants of budget increases over time. This could be because higher incomes mean greater ability of music lovers to contribute to annual giving campaigns, because orchestras must raise their musicians' salaries more when their non-musical neighbors enjoy substantial income gains, or (more speculatively) because the metropolitan areas with the most rapidly rising incomes were those in which highly-educated work force members both contributed to extraordinary economic dynamism and had aboveaverage appreciation for classical music.

Further insight is provided in Table 2, with the size of

22 . Specifically, the Across regressions analyze the means of the three years, while the Within regressions analyze the deviations of each observation from its three-year mean. When there were missing observations, the Across values are averages for the smaller number of years with data.

23 . For differences from three-period variable means in logarithms of the variables, the Pearsonian correlations with INCOME are 0.712 for ENDOWMENT, 0.704 for POPULATION, 0.558 for ASSETS, and 0.090 for COUNT. 
orchestras' endowments taken as the variable to be explained. ${ }^{24}$ From the pooled regressions, it is clear that corporate presence matters for the size of endowments. This is confirmed in the Across regressions. Both ASSETS and (somewhat more strongly) headquarters counts have a significant positive impact, while inter-city per-capita income differences are statistically insignificant. Population size appears not to matter or even to be negative, implying the possibility that in larger cities giant corporations exhibit more of a free-rider mentality. Turning, however, to the Within regressions, we see that increases in per-capita income have by far the strongest influence. INCOME draws explanatory power away from POPULATION and ASSETS, which are positive and significant in analogues of regressions (2.1) and (2.2) without the INCOME variable (not explicitly reported). Larger endowments in turn, as we have seen in Table 1, are associated with substantially higher orchestra operating budgets.

24 . The data base is not sufficiently rich in theoretically- motivated exogenous variables to use a two-stage approach, in which an instrumented prediction of ENDOW would be substituted for the actual values in the Table 1 regressions. 
Table 2: REGRESSIONS WITH LOG ENDOWMENT AS DEPENDENT VARIABLE*

\begin{tabular}{|c|c|c|}
\hline & $(2.1)$ & $(2.2)$ \\
\hline & \multicolumn{2}{|c|}{ Pooled } \\
\hline POPULATION & $\begin{array}{l}-.233 \\
(0.81)\end{array}$ & $\begin{array}{l}-.588 \\
(1.93)\end{array}$ \\
\hline ASSETS & $\begin{array}{c}.575 \\
(4.14)\end{array}$ & \\
\hline COUNT & & $\begin{array}{c}1.01 \\
(5.11)\end{array}$ \\
\hline INCOME & $\begin{array}{c}2.12 \\
(2.77)\end{array}$ & $\begin{array}{c}2.75 \\
(3.88)\end{array}$ \\
\hline INTERCEPT & $\begin{array}{l}-9.64 \\
(3.20)\end{array}$ & $\begin{array}{l}-9.54 \\
(3.34)\end{array}$ \\
\hline $\mathrm{N}$ & 101 & 101 \\
\hline \multirow[t]{2}{*}{$\mathrm{R}^{2}$} & .410 & .453 \\
\hline & \multicolumn{2}{|c|}{ Across } \\
\hline POPULATION & $\begin{array}{l}-.516 \\
(1.00)\end{array}$ & $\begin{array}{l}-.844 \\
(1.65)\end{array}$ \\
\hline ASSETS & $\begin{array}{c}.762 \\
(3.06)\end{array}$ & \\
\hline COUNT & & $\begin{array}{c}1.41 \\
(3.80)\end{array}$ \\
\hline INCOME & $\begin{array}{c}1.94 \\
(0.84)\end{array}$ & $\begin{array}{c}.273 \\
(0.12)\end{array}$ \\
\hline INTERCEPT & $\begin{array}{l}-8.79 \\
(0.98)\end{array}$ & $\begin{array}{c}1.27 \\
(0.14)\end{array}$ \\
\hline $\mathrm{N}$ & $\begin{array}{l}35 \\
(\mathrm{co}\end{array}$ & 35 \\
\hline
\end{tabular}


Table 2(Continued)

\begin{tabular}{lcc}
$\mathrm{R}^{2}$ & .435 & .497 \\
& \multicolumn{2}{c}{ Within } \\
POPULATION & .540 & .490 \\
& $(0.94)$ & $(0.86)$ \\
ASSETS & .103 & \\
& $(0.95)$ & .241 \\
COUNT & & $(1.42)$ \\
& & 2.73 \\
INCOME & 2.53 & $(6.60)$ \\
& $(5.90)$ & .001 \\
INTERCEPT & .001 & $(0.07)$ \\
& $(0.06)$ & 101 \\
$\mathrm{~N}$ & 101 & .510 \\
$\mathrm{R}^{2}$ & .519 &
\end{tabular}

* T-ratios are given in subscripted parentheses. 


\section{Conclusion}

The results reported here should be viewed as more suggestive than definitive. Although they come from a considerable data-gathering effort, the regression panels cover only three years, and it would be desirable to conduct further analyses utilizing a wider array of explanatory variables. More detailed case study evidence would also help. Nevertheless, the orchestra budget regressions yield plausible implications. Budgets are more generous, allowing inter alia the payment of more generous salaries and hence superior access to the most talented musicians, in cities with a large population base and hence larger potential audiences. Holding population constant, the presence of corporate headquarters with their well-paid staffs and their command over substantial assets leads to higher local orchestra budgets. This occurs in part because local audience members are more affluent than they might otherwise be (shown also by the strong role of per-capita income) and also by enlarging the base of philanthropic contributions to orchestras' budgets and their endowments. The size of endowments is clearly a key variable explaining the magnitude of operating budgets. ${ }^{25}$ The dynamics of how endowments and hence budgets are affected by changes in corporate headquarters locations are left imperfectly illuminated. It seems likely that the effects are complex, with relocations attributable to mergers helping in some ways and hurting in others.

The compilation of corporate asset tallies and headquarters location information confirms that the 1980 s and 1990 s were marked by waves of corporate control transactions almost unprecedented in magnitude. Largely because of acquisitions but also because of relocation decisions not directly influenced by merger, some cities have experienced a flight of corporate wealth while others have gained. In terms of asset shares, the game is zero-sum, with asset gains in some locations benefitting local cultural institutions while losses in other locations have the opposite effect. It is nevertheless of interest that regions of the United States without major symphony orchestras have experienced only a modest headquarters asset share gain. They also had smaller increases in constant-dollar per-capita income. We saw too that among cities with orchestras, the

25 . This point is emphasized by Dempster (2002), pp. 15 and 20. 
distribution of asset control became more equal over time. Thus, the main consequence appears to have been a wider dispersion of potential financial support for musical culture. 


\section{REFERENCES}

William J. Baumol and William J. Bowen, "On the Performing Arts: The Anatomy of Their Economic Problems," American Economic Review, vol. 55 (May 1965), pp. 495-502.

Betty Bock, Harvey J. Goldschmid, Ira M. Millstein, and F. M. Scherer, The Impact of the Modern Corporation (Columbia University Press: 1984).

Richard E. Caves, Creative Industries (Harvard University Press: 2000 ).

N. R. Collins and L. E. Preston, "The Size Structure of the Largest Industrial Firms," American Economic Review, vol. 51 (December 1961), pp. 986-1011.

Douglas J. Dempster, "The Wolf Report and Baumol's Curse: The Economic Health of American Symphony Orchestras in the 1990s and Beyond," Harmony, October 2002, pp. 1-22.

Peter Dobrin, "Palm Beach Overture," Philadelphia Inquirer, April 3, 2005, p. M1.

Deidre A. Gaquin and Katherine de Brandt, County and City Extra: 2006; Annual Metro, City, and County Data Book (Lanham, MD: Berman Press, 2006).

Stanley N. Katz, "Philanthropy," working paper, August 2004, forthcoming in Victor Ginsburgh, ed., Handbook of Cultural Economics.

Mark S. Leclair and Kelly Gordon, "Corporate Support for Artistic and Cultural Activities," Journal of Cultural Economics, vol. 24 (August 2000), pp. 225-241.

Christopher Marquis and Gerald F. Davis, "Golfing Alone? Local Corporations, Elite Cohesion and Community Social Capital, 1986-1998," working paper, University of Michigan, September 2004 .

Katherine Maddox McElroy and John J. Siegfried, "The Effect of Firm Size and Mergers on Corporate Philanthropy," in Bock et al., eds, The Impact of the Modern Corporation, pp. 99-155. 
Peter Navarro, "Why Do Corporations Give to Charity?" Journal of Business, vol. 61 (January 1988), pp. 65-93.

John O'Hagan and Denice Harvey, "Why Do Companies Sponsor Arts Events?" Journal of Cultural Economics, vol. 24 (August $2000)$, pp. 225-241.

F. M. Scherer, "A New Retrospective on Mergers," Industrial Organization Review, xxx 2006, pp. xx-xx.

J. Mark Schuster, "Tax Incentives in Cultural Policy," draft paper (August 2004), forthcoming in Victor Ginsburgh, ed., Handbook of Cultural Economics.

Michael Useem and Stephen Kutner, "Corporate Contributions to Culture and the Arts," in Paul DiMaggio, ed., Nonprofit Enterprise in the Arts (Oxford University Press: pp. 93-113.

U.S. Department of Commerce, Bureau of the Census, State and Metropolitan Area Data Book ( $3 r d$ and 5th editions; Washington: 1986 and 1998). 